\title{
Balancing the benefits of $n-3$ polyunsaturated fatty acids and the risks of methylmercury exposure from fish consumption
}

\section{Citation}

Mahaffey, Kathryn R, Elsie M Sunderland, Hing Man Chan, Anna L Choi, Philippe Grandjean, Koenraad Mariën, Emily Oken, et al. 2011. "Balancing the Benefits of n-3 Polyunsaturated Fatty Acids and the Risks of Methylmercury Exposure from Fish Consumption." Nutrition Reviews 69 (9) (September): 493-508. doi:10.1111/j.1753-4887.2011.00415.x.

\section{Published Version}

doi:10.1111/j.1753-4887.2011.00415.x

\section{Permanent link}

http://nrs.harvard.edu/urn-3:HUL.InstRepos:34767900

\section{Terms of Use}

This article was downloaded from Harvard University's DASH repository, and is made available under the terms and conditions applicable to Other Posted Material, as set forth at http:// nrs.harvard.edu/urn-3:HUL.InstRepos:dash.current.terms-of-use\#LAA

\section{Share Your Story}

The Harvard community has made this article openly available.

Please share how this access benefits you. Submit a story.

Accessibility 
Published in final edited form as:

Nutr Rev. 2011 September ; 69(9): 493-508. doi:10.1111/j.1753-4887.2011.00415.x.

\title{
Balancing the benefits of $n-3$ polyunsaturated fatty acids and the risks of methylmercury exposure from fish consumption
}

\author{
Kathryn R Mahaffey \\ Department of Occupational and Environmental Health, George Washington University School of \\ Public Health, Washington DC, USA

\section{Elsie M Sunderland} \\ Department of Environmental Health, Harvard School of Public Health, Boston, Massachusetts, \\ USA

\section{Hing Man Chan} \\ Community Health Sciences Program, University of Northern British Columbia, Prince George, \\ British Columbia, Canada
}

\author{
Anna L Choi \\ Department of Environmental Health, Harvard School of Public Health, Boston, Massachusetts, \\ USA
}

\section{Philippe Grandjean}

Department of Environmental Health, Harvard School of Public Health, Boston, Massachusetts, USA, and Institute of Public Health, University of Southern Denmark, Odense, Denmark

\section{Koenraad Mariën}

Washington State Department of Health, Olympia, Washington DC, USA

\section{Emily Oken}

Department of Population Medicine, Harvard Medical School and Harvard Pilgrim Health Care Institute, Boston, Massachusetts, USA

\section{Mineshi Sakamoto}

Department of Epidemiology, National Institute for Minamata Disease, Minamata, Fukuoka, Japan

\section{Rita Schoeny}

US Environmental Protection Agency, Office of Water, Washington DC, USA

\section{Pál Weihe}

Faroese Hospital System, Tórshavn, Faroe Islands

\section{Chong-Huai Yan}

Shanghai Key Laboratory of Children's Environmental Health, XinHua Hospital, Shanghai Jiao Tong University School of Medicine, Shanghai, China

\section{Akira Yasutake}

Biochemistry Section, National Institute for Minamata Disease, Minamata, Fukuoka, Japan

\section{Abstract}

\section{(C) 2011 International Life Sciences Institute}

Correspondence: HM Chan, Community Health Sciences Program, University of Northern British Columbia, Prince George, British Columbia, Canada, V2N 4Z9. lchan@unbc.ca, Phone: +1-250-960-5237..

Declaration of interest. The authors have no relevant interests to declare. 
Fish and shellfish are widely available foods that provide important nutrients, particularly n-3 polyunsaturated fatty acids (n-3 PUFAs), to many populations globally. These nutrients, especially docosahexaenoic acid, confer benefits to brain and visual system development in infants and reduce risks of certain forms of heart disease in adults. However, fish and shellfish can also be a major source of methylmercury ( $\mathrm{MeHg}$ ), a known neurotoxicant that is particularly harmful to fetal brain development. This review documents the latest knowledge on the risks and benefits of seafood consumption for perinatal development of infants. It is possible to choose fish species that are both high in n-3 PUFAs and low in MeHg. A framework for providing dietary advice for women of childbearing age on how to maximize the dietary intake of n-3 PUFAs while minimizing $\mathrm{MeHg}$ exposures is suggested.

\author{
Keywords \\ docosahexaenoic acid; eicosapentaenoic acid; fish; methylmercury; $n-3$ polyunsaturated fatty \\ acids
}

\title{
INTRODUCTION
}

Fish and shellfish are important food resources globally. About $20 \%$ of the world's population derives at least one-fifth of its animal protein intake from fish, which contributes up to $180 \mathrm{kcal}$ per capita per day in island states such as Iceland and Japan. ${ }^{1}$ Consuming fish has many health benefits due in part to the high concentrations of $n-3$ polyunsaturated fatty acids (n-3 PUFAs) present in many species. However, fish also contain methylmercury $(\mathrm{MeHg})$, a well-known and widespread environmental neurotoxicant. Most human exposure to $\mathrm{MeHg}$ is through fish consumption. ${ }^{2-5}$ Fetuses are a high-risk group because the developing brain is particularly susceptible to the harmful effects of MeHg exposure. ${ }^{6}$ Therefore, the effect of dietary seafood intake by pregnant women remains an important issue, especially in populations that consume fish frequently. ${ }^{7}$ Reviewing the scientific evidence that forms the basis of dietary and public health advice on how to balance the benefits and risks associated with fish consumption is therefore needed. Although this review is focused on providing advice for women of childbearing age, risks for the general population associated with $\mathrm{MeHg}$ exposures, such as impacts on the endocrine system and cardiovascular health, are the subject of much ongoing research. ${ }^{8-13}$

This review focuses on the combined effects of MeHg and n-3 PUFA exposures in women of childbearing age on subsequent fetal and child development. The scope of this review includes the following: 1) intake and metabolism of n-3 PUFAs; 2) effects of n-3 PUFA intakes on child development; 3) MeHg exposure from fish consumption; 4) MeHg body burden and child development; 5) transfer of n-3 PUFAs and MeHg from mothers to fetuses; 6) complexity of the association between MeHg exposure and dietary sources of n-3 PUFAs; 7) dietary recommendations for pregnant women; and 8) balancing the risks and benefits of fish consumption.

\section{INTAKE AND METABOLISM OF n-3 PUFAS}

Fatty acids are chemicals that contain carbon, oxygen, and hydrogen in repeating groups of $-\left(\mathrm{CH}_{2}\right)_{n}$ - that contain both a methyl $\left(\mathrm{CH}_{3}\right)$ and a carboxyl $(-\mathrm{COOH})$ group. There are a large number of fatty acids found in nature. ${ }^{14}$ Highly unsaturated fatty acids (multiple double bonds) with one of the double bonds located three carbon atoms from the methyl end are denoted n-3 fatty acids. Those n-3 PUFAs that are particularly important in human nutrition ${ }^{15}$ include the following: 18:3 alpha-linolenic acid (ALA), 20:5 eicosapentaenoic acid (EPA), 22:5 docosapentaenoic acid (DPA), and 22:6 docosahexaenoic acid (DHA). 
The two fatty acids that are especially important for human neurological development are EPA (20 carbons in length with five double bonds including one at n-3), and DHA (22 carbons in length with six double bonds, including one at $n-3$ ). These essential fatty acids play important roles in the following areas: 1) cell membrane formation, integrity, and functions; 2) functioning of brain, retina, liver, kidney, adrenal glands, and gonads; and 3) local hormone production for the regulation of blood pressure and immune and inflammatory responses. ${ }^{16}$

Humans can synthesize portions of their requirements for elongated $n-3$ fatty acids from the short-chain precursor ALA. ${ }^{15,17}$ ALA is present in dietary sources such as walnuts, flax seed, and soybean oil. However, synthesis of EPA and DHA from ALA is generally not sufficient to meet dietary requirements. ${ }^{18,19}$ As EPA and DHA are essential nutrients, dietary intake from fish and shellfish, enriched eggs, and/or food supplements is necessary for adequate levels.

The capacity of humans to synthesize EPA and DHA from ALA is variable. Conversion efficiency is organ-specific ${ }^{20}$ and also varies substantially from person to person. ${ }^{21}$ For example, women appear to be able to convert dietary ALA to the long-chain fatty acids more readily than men. ${ }^{17,22,23}$ Synthesis of EPA and DHA in the human body from ALA is likely inhibited by conditions of disease (for example, liver toxicity) ${ }^{18,19}$ and appears to decline with exposure to environmental contaminants, such as polychlorinated biphenyls (PCBs), drugs, and other nutrients. ${ }^{24,25}$

It is not known if humans can synthesize DHA from ALA at a rate sufficient to provide an optimal amount of this chemical to meet the demands of the developing fetal brain. Halflives of DHA in critical tissues, including the brain, vary with the adequacy of the dietary supply. ${ }^{26}$ Wide inter-individual variability exists in the ability to synthesize DHA, especially among term and preterm infants. ${ }^{18}$ The fetus may be limited in its ability to form adequate DHA from precursors ${ }^{18}$ and thus need to receive preformed DHA through placental transfer from the mother. ${ }^{27}$ Maternal DHA stored in adipose tissue may be mobilized during pregnancy by placental regulation. ${ }^{28-31}$ However, fetal DHA does not increase one-for-one with maternal serum DHA concentration. ${ }^{18,28}$ This complex topic is the focus of ongoing research.

Globally, the most commonly consumed sources of n-3 PUFAs are fish and shellfish, which in turn obtain them from algae that can synthesize these fatty acids. Concentrations of $n-3$ PUFAs vary greatly among fish species. ${ }^{32-37}$ Thus, dietary intake of EPA and DHA from fish and shellfish is strongly dependent on the species consumed. . $^{3,33,38,39}$ Lipid content of specific fish is moderately predictive of their n-3 PUFA content. For example, certain fatty fish (especially salmon, mackerel, sardines, and herring) are also high in n-3 PUFAs.

However, other fish that are low in fat (especially shrimp and trout) are also good sources of n-3 PUFAs. Table 1 provides a summary of n-3 PUFA levels in multiple fish and shellfish varieties.

Weaver et al. ${ }^{34}$ evaluated the species most commonly consumed in North America and grouped them by n-3 PUFA content into those providing more than $500 \mathrm{mg}, 150-500 \mathrm{mg}$, or less than $150 \mathrm{mg}$ per $100 \mathrm{~g}$ of fish consumed. Fish species that provide the highest levels of n-3 PUFAs are sockeye salmon, farmed trout, farmed salmon, Copper River salmon, Coho salmon, brozini, fresh bluefin tuna, albacore tuna canned in water, and toothfish. Species providing less than $150 \mathrm{mg}$ of $\mathrm{n}-3$ PUFAs per $100 \mathrm{~g}$ fish meals include mahi-mahi, skate, triggerfish, monkfish, red snapper, wahoo, grouper, corvina, and tuna canned in oil. Species intermediate in n-3 PUFAs are haddock, cod, halibut, sole, flounder, crustacea, perch, black 
bass, tilapia, and swordfish. These groups reflect only their n-3 fatty acid content, not the mercury concentrations present.

Dietary intake levels and sources of n-3 PUFAs vary among countries. In countries such as Japan, fish, shellfish, and edible fats and oils are the most important sources of n-3 PUFAs. The Japanese diet is relatively low in fat with an average seafood consumption rate of approximately $60 \mathrm{~g} / \mathrm{day}$, which represents $26 \%$ of total energy intake. ${ }^{40}$ Average intake of n-3 PUFAs is reported to be approximately 3,000 mg/day, mostly from fish species such as horse mackerel, sardines, and tuna. ${ }^{40}$ In contrast, intake of and, accordingly, blood levels of DHA in the United States are among the lowest in the world. ${ }^{41}$ Similarly, there is evidence that many women of childbearing age in Canada do not consume enough DHA to meet nutritional requirements for optimal fetal development. ${ }^{42,43}$

\section{EFFECTS OF n-3 PUFA INTAKE ON CHILD DEVELOPMENT}

DHA is a necessary structural component of the developing brain and eye (see review by Innis $^{44}$ ). Because the uptake of DHA into these tissues is greatest in the third trimester of pregnancy and the first 2 years of life, the pre- and post-natal periods represent critical windows for exposure. ${ }^{45,46}$ Randomized trials of prenatal supplementation and observational studies of maternal fish consumption during pregnancy both provide evidence for the benefits of prenatal n-3 PUFA intake for child development. Helland et al. ${ }^{47}$ conducted a trial in which pregnant women were randomly assigned to receive either a cod liver oil (n-3 PUFA) supplement or a corn oil supplement (n-6 long-chained polyunsaturated fatty acid [n-6 PUFA] control) from 18 weeks of gestation until 3 months postpartum. Corn oil is not a suitable precursor for n-3 PUFA synthesis. At age 4 years, offspring whose mothers had received cod liver oil supplements had significantly higher mean scores on developmental and cognitive tests than the control group. In another trial by Dunstan et al. ${ }^{48}$ children of mothers who received fish oil supplements during pregnancy had significantly higher scores on eye and hand coordination tests compared to those who received olive oil. Eye and hand coordination scores at 2.5 years of age were positively correlated with n-3 PUFA levels in cord blood erythrocytes and inversely correlated with n-6 PUFA levels. ${ }^{48}$ However, no differences in other outcomes such as child behavior and language at age 2.5 years were observed. ${ }^{48}$ Because these studies used fish oil rather than an n-3 PUFA supplement from algae, PCB contamination of the fish oils may have occurred, which could have resulted in underestimates of the benefits of n-3 PUFA intakes. ${ }^{49} \mathrm{In}$ addition, follow-up rates in both studies were low, which might bias results.

Observational studies have also consistently shown that mothers who consume more n-3 PUFAs during pregnancy have children with improved neurobehavioral development. For example, Oken et al. ${ }^{6,50}$ examined associations among maternal prenatal fish intake, mercury levels, and cognitive development in offspring at 6 months to 3 years of age in Project Viva, a pre-birth cohort in the state of Massachusetts in the United States. Greater maternal fish consumption (assumed to indicate higher n-3 PUFA intake) was associated with higher infant and child cognitive scores. Mothers who consumed more than two servings of fish weekly and sustained low blood mercury levels (presumably because they consumed fish with low mercury levels) had children with the highest test scores. The beneficial association of fish consumption with offspring cognition was strengthened with additional adjustment for mercury levels, suggesting that the benefits of prenatal fish consumption might be even greater in the absence of mercury contamination. Similarly, among a cohort of over 25,000 mothers and children in Denmark, the highest versus the lowest quintile of fish intake was associated with higher child developmental scores at 18 months. ${ }^{51}$ In the Avon Longitudinal Study of Parents and Children (ALSPAC) study, which included 11,875 mothers and children from the United Kingdom, ${ }^{52}$ mothers who ate more 
than $340 \mathrm{~g}$ (12 ounces) of low-mercury seafood per week had a lower risk of having children with suboptimal scores on measures of verbal IQ, prosocial behavior, fine motor skills, and social development compared with women who ate less seafood. In another UK study, at age 9 years, the children of mothers who had eaten oily fish in late pregnancy had a reduced risk of hyperactivity and a higher verbal IQ, but no difference in full-scale IQ, compared with those whose mothers did not eat fish. ${ }^{53}$ Finally, in a cohort of children in New York City, maternal fish consumption was associated with better psychomotor development at 36 months and higher verbal and full IQ scores at 48 months of age. ${ }^{54}$ It is important to note that the levels of exposure to $\mathrm{MeHg}$ from fish consumption in many of these studies were fairly low compared to populations that consume large quantities of fish on a regular basis.

Dietary n-3 PUFA intake in infancy may also improve later cognitive development, although evidence for such benefits is less clear. Breast milk is a rich source of n-3 PUFAs. Before 2002, commercial infant formulas in the United States contained ALA, but not long-chain fatty acids. ${ }^{55} \mathrm{~A}$ meta-analysis of observational studies showed a 3-5-point increase in IQ among children who had been fed breast milk compared to those fed with infant formula that was not supplemented with long-chain fatty acids. ${ }^{56}$ The extent to which residual confounding explains these results is a major concern. ${ }^{57}$ However, in a cluster-randomized trial of 17,000 mothers and children in the Republic of Belarus, children whose mothers were randomized to a breastfeeding promotion intervention had higher IQ at age 6.5 years, suggesting that confounding does not entirely explain the observed benefit. Several randomized trials have attempted to determine whether the use of infant formulas supplemented with long-chain fatty acids (n-3 and n-6 PUFAs) is associated with improved outcomes compared to non-supplemented formula. ${ }^{58,59}$ Meta-analyses of these randomized controlled trials did not find evidence of persistent beneficial effects of n-3 and n-6 PUFA supplementation of formula milk on the physical, visual, and neurodevelopmental outcomes of term or preterm infants followed up to 3 years of age. ${ }^{58-60}$ Thus, the beneficial effects of breastfeeding may be related to factors other than the elongated fatty acid content of breast milk.

\section{METHYLMERCURY EXPOSURE FROM FISH CONSUMPTION}

In addition to containing n-3 PUFAs, which may benefit child neurodevelopment, fish also contains $\mathrm{MeHg}$, which can damage the fetal nervous system. ${ }^{61-65}$ Dose-response relationships between indicators of neurodevelopmental effects in children and $\mathrm{MeHg}$ exposures have been quantified with sufficient confidence ${ }^{66}$ to apply in regulatory decisions controlling mercury emissions. ${ }^{67,68}$

Inorganic mercury from atmospheric deposition and other sources is converted to $\mathrm{MeHg}$, the only mercury species that biomagnifies in aquatic food webs, ${ }^{69}$ by microbes in the water and sediments of wetlands, lakes, reservoirs, rivers, estuaries, and oceans. ${ }^{70-73}$ Larger, older, and higher-trophic-level fish species generally have higher MeHg tissue residues than smaller and younger organisms from lower trophic levels. ${ }^{69}$ Concentrations in top predator fish can be up to 10 million times higher than those in water. ${ }^{69,74,75} \mathrm{MeHg}$ levels in fish and shellfish reflect concentrations in their diet (prey items), the level of contamination in the system from which they were harvested, and species-specific physiological factors such as metabolism and growth rate. ${ }^{76-79}$ Yet, apart from species type, consumers generally have limited access to information about MeHg concentrations in fish. Such challenges highlight the need for additional information on harvesting regions and size of fish sold in the commercial market.

Table 1 shows MeHg concentrations in commonly consumed fish and shellfish. Hightrophic-level species like shark, tilefish, swordfish, and large bluefin tuna (used in sashimi 
grade tuna) are consistently high in $\mathrm{MeHg}$. As a result, dietary advisories for limiting consumption by high-risk groups have been issued for these species in many countries. Fish with low-to-moderate $\mathrm{MeHg}$ concentrations such as mackerel, salmon, and sardines have some of the highest n-3 PUFA contents (Table 1). Other commonly consumed low-MeHg seafood include herring, pollock, flounder, sole, plaice, crabs, shrimp, and oysters. ${ }^{80,81}$

\section{METHYLMERCURY BODY BURDEN AND CHILD DEVELOPMENT}

Three long-term studies have investigated MeHg impacts in children exposed prenatally with continued exposure into adulthood. Two of these studies (based in the Faroe Islands and the Seychelles) are ongoing, and the third, conducted in New Zealand, was completed in the 1980s. ${ }^{62,82-92}$ The New Zealand study considered children whose mothers were frequent seafood consumers and compared a group with a low $\mathrm{MeHg}$ exposure to a group with hair$\mathrm{Hg}$ concentrations above $6 \mu \mathrm{g} / \mathrm{g}$ (mean, $8.3 \mu \mathrm{g} / \mathrm{g}$ ). ${ }^{64} \mathrm{MeHg}$ exposure was associated with poorer scores on full-scale IQ, language development, and gross-motor skills. ${ }^{64}$ The findings of this study are important because they reflect effects associated with chronic exposures from high and relatively constant fish consumption patterns over time and $\mathrm{Hg}$ body burdens in homeostasis.

The Faroe Islands study is following a cohort of more than 1,000 singleton births in a population of frequent fish consumers that also periodically consumes whale meat and blubber. ${ }^{62,86,90}$ Whale meat is known to contain mercury and the blubber is known to be contaminated with PCBs and other persistent organic chemicals. ${ }^{86}$ The median maternal hair-Hg concentration in this cohort, collected at delivery, was $4.3 \mu \mathrm{g} / \mathrm{g} .{ }^{86}$

Neuropsychological tests administered to offspring at ages 7 and 14 years showed statistically significant indicators of poorer neurodevelopment with higher maternal $\mathrm{MeHg}$ exposure. ${ }^{62,90,93,94}$ The test outcomes associated with the observed effects from $\mathrm{MeHg}$ exposure were not affected when controlling for PCB exposure. ${ }^{95}$ However, the neurotoxic effect from $\mathrm{MeHg}$ exposure observed at ages 7 and 14 years did increase when controlling for maternal fish intake. ${ }^{95}$

The Seychelles study includes more than 800 infant-mother pairs and, in contrast to the New Zealand and Faroe Islands studies, has not initially shown a statistically significant association between maternal mercury exposures and postnatal neurodevelopment. ${ }^{91,92,96}$ Women participating in the Seychelles study demonstrated a similar median maternal hair$\mathrm{Hg}$ level of $6.6 \mu \mathrm{g} / \mathrm{g}$ compared to those of the other two populations at time of delivery. ${ }^{91}$ The first series of results was adjusted for the child's postnatal MeHg exposure, but not for maternal fish intake. A direct association between maternal $\mathrm{MeHg}$ exposure and poorer developmental scores, after adjustments were made for fish intake, was recently reported among a new cohort of children in the Seychelles study, who were followed to 24 months of age. ${ }^{97}$

Results from these three studies were central to the conclusions derived by the National Academy of Sciences in 2000, ${ }^{98}$ which the US Environmental Protection Agency (EPA) subsequently used to derive the reference dose (RfD) for MeHg of $0.1 \mu \mathrm{g} / \mathrm{kg} / \mathrm{day}$. This RfD was based on a series of endpoints associated with a median cord blood mercury level of about $58.0 \mu \mathrm{g} / \mathrm{L}$. As noted in the US EPA Integrated Risk Information System (IRIS), the EPA did not choose a single endpoint for the RfD: "Rather than choose a single measure for the RfD critical endpoint, EPA based this RfD for this assessment on several scores from the Faroes measures, with supporting analyses from the New Zealand study, and the integrative analysis of all three studies." 99 In calculating the RfD, the EPA assumed that cord blood and maternal blood mercury levels were equivalent. ${ }^{100}$ 
Generally, an RfD is defined as the amount of a substance that can be consumed on a daily basis for a lifetime by the population, including sensitive subpopulations, without the expectation of an adverse effect. ${ }^{101}$ It should be noted, however, that for the MeHg RfD, IRIS says the following:"It is also important to note that no evidence of a threshold arose for methylmercury-related neurotoxicity within the range of exposures in the Faroe Islands study." "99 Recent studies have observed effects at exposures near or below the current EPA RfD. Lederman et al. ${ }^{54}$ studied a cohort of children who had the potential for mercury exposure by virtue of the fact that their mothers lived within 1 or 2 miles of World Trade Center in New York City around the time of its collapse on September 11, 2001. Blood mercury levels were significantly higher in women who consumed fish or seafood while pregnant; there was no significant effect of residence near the World Trade Center site. The authors observed a significant inverse association between log cord mercury and Psychomotor Development Index scores at 36 months as well as with performance and verbal and full IQ scores on the Wechsler Preschool and Primary Scale of Intelligence Revised (WPPSI-R), administered at 48 months. They noted that no child with a cord blood mercury level above $13 \mu \mathrm{g} / \mathrm{L}$ had a full IQ score higher than 100 . The authors state that other published studies reported higher mean cord blood mercury than those measured in their cohort; for example, the cord blood geometric mean mercury level in the Faroe Islands study was $22.9 \mu \mathrm{g} / \mathrm{L}$.

The MeHg RfD determined by the US EPA has been used to derive biomonitoring comparison values considered to reflect exposures equivalent to the RfD; such as $1.2 \mu \mathrm{g} / \mathrm{g}$ (ppm) mercury-in-hair concentration and $5.8 \mu \mathrm{g} / \mathrm{L}(\mathrm{ppb})$ mercury-in-blood concentration. ${ }^{101}$ Additional evaluations of the amounts of $\mathrm{MeHg}$ that produce adverse health effects have been developed by various organizations, including the World Health Organization, and are summarized by Mergler et al. ${ }^{65}$ Governmental agencies representing a number of countries (such as Japan, USA, New Zealand, Australia, UK, and Canada) have developed MeHg intake levels to protect the public that range from $0.1-0.47 \mu \mathrm{g} / \mathrm{kg} / \mathrm{day} .{ }^{98,102-104}$ Differences among various government assessments are mainly related to the amounts of exposure considered to be without adverse effects rather than estimates of exposures producing adverse effects. Various agencies have applied different uncertainty factors to extrapolate from exposures known to produce adverse effects to exposures thought to be safe. For example, the US EPA applied an uncertainty factor of 10 to results from the Faroe Islands population, as well as other study results to account for variability and uncertainty within the human population. ${ }^{101}$ In contrast, the Agency for Toxic Substances and Disease Registry (ATSDR) applied a factor of 4.5 for human variability and uncertainty in the sensitivity of the tests used in the Seychelles study, on which their assessment was based. ${ }^{105}$ Uncertainty factors will remain varied until various issues can be addressed. This imprecision will bias the estimation of $\mathrm{MeHg}$ neurotoxicity toward null. For example, recent work conducted in the Faroe Islands population adjusted for the imprecision of exposure biomarkers resulted in a calculated RfD that is about $50 \%$ below the level used by the US EPA. ${ }^{106}$

Various studies suggest that many populations and/or subpopulations exceed a body burden level that risk assessors consider acceptable. Results from Project Viva in the United States, which included 135 mother-infant pairs from a mostly white,educated, and middle- to uppermiddle-class population, indicated that approximately $10 \%$ of women exceeded a hair mercury level equivalent to the US EPA RfD. ${ }^{6}$ These results are similar to those observed in the National Health and Nutrition Examination Survey (NHANES), which showed that between 1999 and 2002 approximately $6 \%$ of women of childbearing age exceeded the US EPA's RfD for MeHg. ${ }^{3}$ NHANES data are collected across the United States using a weighted approach to participant selection so as to result in a statistical representation of the general population. The most recent NHANES data for 2004 suggest that blood mercury concentrations in women of childbearing age may be decreasing, although the amounts of 
fish consumed by high-risk individuals have not changed. ${ }^{4}$ Regional studies indicate that blood mercury levels in adults living in New York City are three times those of the national average.${ }^{107}$ Foreign-born Chinese residents of New York City had the highest blood mercury levels of all ethnic groups, with a geometric mean of $7.26 \mu \mathrm{g} / \mathrm{L}$ (exceeding the US EPA RfD). ${ }^{107}$ Similar results have been observed within the Korean and Japanese communities in the Arsenic Mercury Intake Biometric Study (AMIBS), in which many women within both communities exceed the MeHg RfD. ${ }^{108-110}$ Results of this study also showed significant differences in MeHg body burden levels between the two populations, even though total fish intake is nearly identical, suggesting differences in fish species selection. ${ }^{108-110}$ Even if body burdens are decreasing among women in the United States, results from Project Viva have shown that women with higher fish consumption patterns leading to elevated mercury body burden levels may have children with decreased cognitive scores. ${ }^{6}$ Further, a recently published work conducted in a New York City cohort that had average maternal blood mercury levels similar to those observed nationally based on NHANES results suggests that impaired cognitive development can occur in children of mothers with exposure levels near the RfD. ${ }^{54}$

Further indication that mercury body burden levels in many individuals are exceeding those recommended comes from the Korean National Human Exposure and Bio-monitoring Examination in which one in three women and one in six children had hair-Hg levels exceeding $1 \mu \mathrm{g} / \mathrm{g} .{ }^{111,112}$ Blood-Hg levels obtained for this examination, which was intended to reflect the general population of Korea, suggested that greater than $25 \%$ of the population have mercury intakes exceeding the US EPA RfD. ${ }^{111,112}$ In certain locations of China, such as Guizhou in the southwest, rice harvested from the mercury-rich environment is a significant contributor to overall $\mathrm{Hg}$ body burdens. ${ }^{113-115}$ Mercury-contaminated rice may also become a significant concern in other areas, such as the Philippines, where in some locations rice is grown in Hg-rich soils. ${ }^{116}$ For example, rice paddy fields along the Naboc River have been irrigated by water from a contaminated river and $\mathrm{Hg}$ intakes from rice for local residents exceed one-third of their total exposure. ${ }^{116}$ Because of the importance of fish and rice in Asian diets, more information on $\mathrm{MeHg}$ exposure from these sources is needed to characterize the risk to Asian populations.

In summary, results of multiple studies have shown that body burden levels of MeHg in many populations around the world are exceeding the levels equivalent to the US EPA RfD. This implies that neurodevelopmental impacts to offspring of mothers exposed to high levels of $\mathrm{MeHg}$ is a substantial global concern.

\section{TRANSFER OF n-3 PUFAS AND METHYLMERCURY FROM MOTHERS TO FETUSES}

Maternal and fetal blood DHA concentrations are significantly correlated. ${ }^{117,118}$ However, the percentage of DHA in the lipids of cord plasma is higher than that in maternal plasma at the time of birth. ${ }^{29,119}$ Several studies show placental fatty acid transport proteins (FATP) and different lipolytic enzymes are of key importance in mediating DHA transport across the human placenta, although the exact mechanism of preferential DHA transfer remains unknown. ${ }^{29,119} \mathrm{MeHg}$ transport into tissues appears to be mediated by the formation of a MeHg-cysteine conjugate, which is transported into cells via a neutral amino acid carrier protein. ${ }^{120,121}$ Various studies have shown difference between the concentration of $\mathrm{MeHg}$ in cord blood and maternal blood concentrations. ${ }^{3,65,122,123}$ Stern and Smith ${ }^{122}$ calculated the geometric mean ratio of fetal to maternal blood mercury to be 1.7. Since this work was completed, Lederman et al. ${ }^{54}$ obtained a ratio of 2.2 in a New York City cohort of pregnant women. As the EPA assumed that cord blood and maternal blood mercury levels to be 
equivalent when calculating the $\mathrm{RfD}$, future adjustments to the $\mathrm{RfD}$ for $\mathrm{MeHg}$ will need to incorporate this difference in fetal-maternal blood ratio.

Sakamoto et al. ${ }^{118}$ reported that $\mathrm{MeHg}$ was directly correlated with DHA in fetal circulation. These results suggest that fish consumption may have been the source of both $\mathrm{MeHg}$ and DHA in maternal circulation that was subsequently transferred to the fetus. If the types of fish consumed are low in $\mathrm{MeHg}$ but rich in DHA,the health of the children will likely improve, but if the $\mathrm{MeHg}$ concentrations are sufficiently elevated to cause deleterious outcomes, the beneficial aspects of DHA intake may be negated. Accordingly, fish consumption would then have an adverse effect on children's development. This salient issue makes the placental transfer of $\mathrm{MeHg}$ and DHA and their relationship in fetal and maternal blood circulation important factors for determining the risks and benefits of maternal fish consumption during gestation.

\section{COMPLEXITY OF THE ASSOCIATION BETWEEN METHYLMERCURY EXPOSURE AND DIETARY SOURCES OF n-3 PUFAS}

Amounts of both n-3 PUFAs and MeHg in fish and shellfish vary widely across and within different fish varieties (Table 1). Some kinds of fish have more than 10 times the amount of EPA and DHA than other species and the amount of mercury in fish can differ by two orders of magnitude (e.g., Table 1). Many species that are high in n-3 PUFAs are low in MeHg and vice-versa, making it possible to choose species that minimize $\mathrm{MeHg}$ exposure while retaining the health benefits of consuming fish. ${ }^{32,39,124} \mathrm{~A}$ number of reports have recommended ways to choose fish and shellfish species that provide higher quantities of n-3 PUFAs and relatively low quantities of MeHg. ${ }^{32,39,125,126}$

$\mathrm{MeHg}$ concentrations in fish consistently increase with trophic level (i.e., biomagnify in the food-web) based on a variety of factors outlined in earlier sections. ${ }^{69}$ In contrast, n-3 PUFAs show irregular retention patterns at different trophic levels. ${ }^{14}$ Fish cannot synthesize n-3 PUFAs and obtain them from algae. Therefore, even lower trophic level fish, such as sardines and anchovies, can have high levels of DHA. The fat content of specific fish species is moderately predictive of their n-3 PUFA content, with certain fatty fish (e.g., salmon, mackerel, sardines, and herring) having especially high levels (Table 1). However, other species that are low in fat (e.g., shrimp and trout) are also good sources of n-3 PUFAs. DHA is primarily found in phospholipids of cell membranes, accumulates in fatty tissues, and shows little relationship with fish body size. ${ }^{14}$ DHA retention by plankton appears to be determined by the taxonomic composition of the food web. ${ }^{14}$ Differences among factors affecting the uptake and accumulation of EPA, DHA, and MeHg in fish species explain the divergent concentrations of these chemicals across species.

Generally, the quantity of MeHg in a particular fish and/or shellfish species and the amount of n-3 PUFAs present in the fish or shellfish species are not consistently associated. ${ }^{32,33}$ NHANES data for women of child-bearing age in the United States show moderate correlations of total fish intake with dietary MeHg intake $(r=0.68)$ and $n-3$ PUFA intake $(r$ $=0.66) .{ }^{127}$ These relationships are strengthened when intakes of MeHg and n-3 PUFAs are considered on a species-specific basis, indicating that the ratio of n-3 PUFAs to MeHg intake depends on the species of fish consumed. ${ }^{127}$

One challenge for interpreting the effects of MeHg and n-3 PUFA exposures on child development relates to exposure estimates that are based on frequency of fish consumption rather than the specific species of fish consumed (e.g., Daniels et al., ${ }^{128}$ Hibbeln et al. ${ }^{52}$ ). Many studies of child development have relied on the frequency of fish consumption to estimate total fish intake or fish intake by category, such as fatty fish. One of the limitations 
of this approach is that the size of the fish serving may be categorically grouped as small (e.g., $30 \mathrm{~g}$ ) or moderate (e.g., 180-250 g), making it difficult to quantify exposures to n-3 PUFAs or MeHg. Many studies do not collect data on the species of fish that are consumed by study participants. Thus, drawing conclusions about exposures from total fish consumption data is particularly difficult when biomonitoring data (i.e., blood or hair mercury concentrations and blood levels of the n-3 PUFAs) are not available.

\section{DIETARY RECOMMENDATIONS FOR PREGNANT WOMEN}

EPA and DHA are considered to be among the major beneficial nutrients obtained from fish consumption. ${ }^{129}$ There are many recommendations for the inclusion of pre-formed EPA and DHA in the human diet. ${ }^{130-132}$ DHA doses of approximately $2,000 \mathrm{mg} /$ day result in near maximal increases in plasma DHA because dietary DHA results in a dose-dependent, saturable increase in plasma DHA concentration. ${ }^{133}$ It is not clear that eating fish in amounts that provide more than 2,000 mg/day of EPA and DHA offers any benefits. Different countries suggest various levels of n-3 PUFA intakes, with recommendations from expert groups ranging from $100 \mathrm{mg} /$ day to $1,600 \mathrm{mg} /$ day of EPA and DHA (summary statement by Gao et al. ${ }^{134}$ ). The Food and Nutrition Board of the National Research Council in the United States ${ }^{15}$ has developed an acceptable macronutrient distribution range for n-3 PUFAs of $0.6-1.2 \%$ of energy intake. This recommended intake would translate to a recommendation of eating two servings of fish (with at least moderate PUFA content) per week.

Many non-fish sources of pre-formed EPA and DHA are available and are especially important for vegetarians and others who cannot or choose not to eat fish. ${ }^{135}$ Sources include DHA and/or EPA supplements extracted from fish organs or tissues (i.e., fish oils) and production by algae.Algae have great capacity for synthesis of the $n-3$ fatty acids ${ }^{136,137}$ and are responsible for more than half the production of n-3 fatty acids at the base of the food chain. ${ }^{138}$ Algae supplements and fish oils can be taken alone or added to foods,such as enriched milk. ${ }^{139-142}$ More than 100 food products in the United States contain added n-3 PUFAs from synthesized micro algae rich in EPA and DHA. DHA from algal-oil capsules has been shown to have the same bioavailability as DHA from cooked salmon. ${ }^{143}$

Eggs are another major non-fish source of n-3 PUFAs. Feeding chickens special diets fortified with fish oil, algae, or ground flax seed can substantially increase the amounts of n-3 PUFAs in hen eggs. ${ }^{144,145}$ Chickens consuming diets fortified by fish oil or algae produce eggs containing EPA and DHA, while added flax seed produces eggs that primarily contain ALA. ${ }^{146,147}$ Hens fed these diets produce eggs containing between $100 \mathrm{mg}$ to more than $500 \mathrm{mg}$ of n-3 PUFAs per $50 \mathrm{~g}$ egg. Free-range or non-caged chickens often obtain diets that increase the n- 3 content of their eggs and specialized chicken-raising procedures are not necessarily required. ${ }^{148}$ Poultry meat may also be a source of n-3 fatty acids. ${ }^{131}$

If human exposure to $\mathrm{MeHg}$ were independent of nutrition from fish, we would aim for zero mercury exposure. Given the nutritional values and cultural importance of fish, much effort has been made by governments at various levels to develop advisories and recommendations to minimize risks associated with $\mathrm{MeHg}$ exposures from fish consumption (e.g., http://www.epa.gov/waterscience/fish/publicinfo.html). Advisories are typically based on measured levels of $\mathrm{MeHg}$ in fish that are combined with values for body weight and portion size to produce an estimate of an acceptable frequency of consumption (e.g., eat no more than once per month). Other advisories suggest choosing fish species at lower trophic levels to lower intake of $\mathrm{MeHg}$ levels without decreasing fish consumption.

Since fish are a source of nutrients and contaminants, both the nutritional elements and contaminant concerns need to be incorporated into dietary recommendations. Public health protection for pregnant women as well as the general public will be improved by cognizance 
of both the potential harm from toxicants and the nutritional benefits when offering these types of recommendations.

Dietary recommendations in the form of fish consumption guidelines frequently attempt to provide quantitative values limiting consumption. One approach for incorporating the beneficial aspects of fish consumption into such recommendations involves quantitatively considering the levels of n-3 PUFA in fish tissue when developing such advice. This approach may allow individuals to concomitantly minimize exposure to contaminants while also ensuring that optimal n-3 PUFA intake is maintained. Many countries have analyzed n-3 PUFA and MeHg levels in their local fish to help public health professionals make the appropriate recommendations. The results of such an approach have been reported, for example, in Bermuda, ${ }^{149}$ Canada, ${ }^{150}$ France, ${ }^{151}$ Spain, ${ }^{152}$ and the United States. ${ }^{32}$ Recommendations on limiting consumption of specific amounts of $\mathrm{MeHg}$, particularly among women of child-bearing age, while promoting fish consumption were made in each case.

Fish consumption advisories issued by public health professionals require careful formulation to ensure effective communication of the risks and benefits in a manner that is accessible to different demographic groups. Such communication represents a considerable and ongoing challenge. For example, Burger and Gochfeld ${ }^{126}$ surveyed fishers in the New York Bight and found that, even though most of the respondents did not have accurate knowledge of the risks and benefits of fish consumption, well over one-third of them did not feel they needed more information. Chien et al. ${ }^{153}$ also found that $67.7 \%$ of 263 women of childbearing age in Taiwan indicated they would not change their amount of fish intake,even though they were told that some fish containing high levels of mercury may be harmful for unborn babies. Verger et al. ${ }^{154}$ studied the effectiveness of advisories for children and women of childbearing age in France. The authors found that although consumer advisories led to a significant decrease in total fish consumption, they had a minimal impact on exposure reductions for high-risk groups because of incorrect recall of high-mercury species. The authors concluded that dietary recommendations should be carefully tested to evaluate long-term memorization in order to become more effective. Similarly, Oken et al. ${ }^{155}$ found that pregnant women in a US cohort reduced their consumption of fish (including tuna, dark-meat fish, and white-meat fish) after dissemination of a wellpublicized federal advisory recommending that pregnant women limit consumption of certain fish because of concerns about $\mathrm{MeHg}$ contamination. In contrast, results from the NHANES data analysis by Mahaffey et al. ${ }^{4}$ showed a statistically significant decline in blood mercury levels for women of childbearing age at the highest exposure levels between 1999 and 2003, and there was no change in reported fish consumption levels. The authors attributed this decline in the fraction of the population exceeding the US EPA's RfD for $\mathrm{MeHg}$ to the federal fish advisory program. These results highlight the importance of effective risk communication for maintaining nutritional benefits associated with fish consumption.

\section{BALANCING THE RISKS AND BENEFITS OF FISH CONSUMPTION}

Many review articles discussing the risk-benefit considerations of fish consumption have been published in recent years (e.g., Costa ${ }^{156}$ ), and a number of nutritional factors have been reported to potentially ameliorate the deleterious effects of $\mathrm{MeHg}$ exposure (see review by Chapman and $\mathrm{Chan}^{157}$ ). The challenges associated with comparing different endpoints and health effects for multiple nutrients and contaminants in fish have typically meant that most studies address the balance of risks and benefits using qualitative metrics (e.g., NAS/ $\mathrm{NRC}^{33}$ ). Most of these qualitative studies emphasize the importance of maintaining or increasing fish consumption in the general population and minimizing exposure to toxic 
contaminants for high-risk groups, such as children, pregnant women, and women of childbearing age, by limiting consumption of certain species. Another approach used in a variety of studies is to compare nutrient and contaminant intakes with published recommended or tolerable intake levels, respectively. For example, Sioen et al. ${ }^{158}$ used the seafood consumption data from the Global Environment Monitoring System and nutrient and contaminant data and calculated exposure to nutrients and contaminants for different countries in the world. They found that countries that consumed high amounts of pelagic oily fish, such as Japan, Korea, Madagascar, the Philippines, and the Nordic-Baltic countries, have high n-3 PUFA and vitamin D intake levels. However, intake of these nutrients is still below the recommended levels. On the other hand, none of the median contaminant concentrations of these countries were above the maximum limits established for the European Union. Therefore, they concluded that the benefits of increased seafood consumption for non-sensitive sub-populations outweigh the risks. It is important to emphasize the need to conduct a more detailed risk-benefits analysis for the sensitive subpopulations that eat the most fish and/or for individuals who eat fish with the highest amounts of MeHg.

Other studies have focused on the epidemiological evidence for specific endpoints, such as cardiovascular risk ${ }^{159,160}$ or child neurodevelopment. ${ }^{161,162}$ Such analyses of epidemiological evidence for the risks and benefits of fish consumption vary substantially in methodology and not surprisingly have shown a variety of results. ${ }^{39,95,160,163}$ Some studies suggest that the benefits from fish consumption may exceed the possible health impacts from contaminant exposure (e.g., Mozaffarian and Rimm ${ }^{160}$; Hibbeln et al. ${ }^{52}$ ), while others (e.g., Budtz-Jorgensen et al. ${ }^{95}$; Oken et al. ${ }^{50}$; Lederman et al. ${ }^{54}$; Daniels et al. ${ }^{128}$ ) have concluded the benefits of fish consumption are overcome or greatly diminished at moderate $\mathrm{MeHg}$ exposure levels. Confounding caused by the simultaneous benefits from n-3 PUFAs and the negative effects of $\mathrm{MeHg}$ exposures from fish consumption presents a challenge for risk-benefit analysis. ${ }^{9,95}$ Both the risks of $\mathrm{MeHg}$ neurotoxicity and the benefits of fish consumption can be underestimated if there are inadequate statistical adjustments for these confounding effects and imprecise exposure estimates. ${ }^{9}$

Several quantitative approaches to evaluating the risks and benefits of fish consumption have recently been proposed. Guevel et al. ${ }^{164}$ developed a common metric based on the quality-adjusted life year method. Their methodology considered the beneficial effects of n-3 PUFAs on the cardiovascular system (CHD mortality, stroke mortality,and morbidity) and the adverse effects of $\mathrm{MeHg}$ on fetal neuronal development (IQ loss or gain). The authors applied the model to analyze the risks and benefits for high fish consumers in France; they found that increasing fish consumption may have a beneficial impact on health but the confidence intervals of the total quality-adjusted life years have a negative lower bound, meaning the benefits may not apply to all individuals, with the uncertainty caused mostly by the impact of $\mathrm{MeHg}$ on cognitive development. The authors also discussed the limitations of this approach, including population specificity, uncertainty associated with the dose-response relationship, possible interactions between different elements, and the respective weight effects of different nutrients and contaminants. Moreover, the cultural or economic preferences of the population were not considered. Therefore, this quantitative approach is a theoretical exercise and further development is needed before it can be applied to public health decision-making.

Two other quantitative approaches that incorporate recommendations regarding the risks and benefits of n-3 PUFAs and MeHg in fish consumption have been suggested. ${ }^{108,163}$ The method developed by Ginsberg and Toal ${ }^{163}$ estimates intakes of MeHg and n-3 PUFAs from individual fish species and then evaluates resulting risks/benefits using dose-response relationships for MeHg risks and n-3 PUFA benefits from the literature. The method 
described by Tsuchiya et al. ${ }^{108}$ attempts to define a ratio between the intake of n-3 PUFA (DHA) and exposure to $\mathrm{Hg}$ that is de minimus, such that an individual consuming a particular fish species can meet the daily recommended intake for this nutrient while not exceeding the US EPA RfD. The intake ratio (using a minimum daily intake for DHA of 100 $\mathrm{mg} /$ day, a daily consumption rate of $60 \mathrm{~g} / \mathrm{day}$, and a body weight of $60 \mathrm{~kg}$ ) was defined as $17 \mathrm{mg}$ DHA to $1 \mu \mathrm{g} \mathrm{Hg}$. As an exercise, the authors used this ratio with published concentrations of MeHg and PUFA in fish tissue to illustrate which species may be most beneficial for consumption (Figure 1). The figure depicts fish species that are below and above the 17:1 ratio, while also indicating which species are above this ratio and provide for less than $6 \mu \mathrm{g}$ of MeHg exposure per day. The $6 \mu \mathrm{g}$ level is the daily intake of a $60 \mathrm{~kg}$ individual at, but not exceeding, the US EPA RfD. Approaches like those developed by Ginsberg and Toal ${ }^{163}$ and Tsuchiya et al. ${ }^{108}$ have limitations yet may be able to provide a useful foundation from which to improve dietary recommendations for fish consumption until the relationships between maternal nutritional status and the effects from prenatal $\mathrm{MeHg}$ exposure are better defined.

\section{CONCLUSION}

Controlling global mercury sources is the best long-term solution for reducing $\mathrm{MeHg}$ concentrations in fish and shellfish. The safety of fish and seafood consumption will remain a concern even while such pollution issues are being addressed. Public health officials worldwide must provide appropriate dietary advice using the best-available understanding of the risks and benefits of seafood consumption. In the last two decades, significant advances have been made in understanding the toxicology and epidemiology of $\mathrm{MeHg}$ exposures as well as the nutritional benefits of n-3 PUFAs. However, a number of knowledge gaps still remain. For example, much more information is needed on the quantities of n-3 PUFAs (EPA, and especially DHA) that can be synthesized from ALA through maternal metabolism. Cohort studies in the Seychelles and Faroe Islands continue to shed light on the impacts of fish intake and $\mathrm{MeHg}$ exposures on pre- and post-natal development ${ }^{84,94,162}$ Other longitudinal studies are considering the association between fish intake and child development at relatively low exposure levels in the United States and Denmark, ${ }^{6,51}$ as well as populations in Canada, China, and Japan that routinely rely on fish as a major dietary staple. ${ }^{134,165,166}$ Unfortu nately, not all studies provided detailed seafood consumption results. This makes conducting a quantitative benefit/risk assessment of DHA intake and $\mathrm{MeHg}$ exposure challenging because seafood consumption remains a major determining factor. The ratio of n-3 PUFAs and MeHg concentrations in individual fish and shellfish species varies considerably. ${ }^{32,33,39}$ Fortunately, it is possible to choose fish species that are both high in n-3 PUFAs and low in MeHg (e.g., Figure 1). This issue becomes more complex when exposure to lipophilic organic contaminants, such as PCBs, are considered (as they also tend to accumulate in predatory fish) or when additional factors, such as other nutrients or variability in individual body weights, are taken into account. Fish and shellfish provide most of the EPA and DHA in diets of people around the world. ${ }^{1}$ Maintaining adequate nutritional intakes of $\mathrm{n}-3$ PUFAs while minimizing exposure to $\mathrm{MeHg}$ from fish remains an important public health goal and quantitative solutions for addressing this issue are beginning to be developed. Ultimately, protecting public health requires dietary strategies, communication, and most of all, longer-term efforts to reduce biological contaminant levels through pollution control.

\section{Acknowledgments}

On June 9, 2009, the National Institute for Minamata Disease in Japan sponsored a special session titled "Methylmercury (MeHg) and n-3 polyunsaturated fatty acid (n-3 PUFA) exposure from fish consumption" at the 9th International Conference on Mercury as a Global Pollutant held in Guiyang, China. The session was international in scope, with speakers from Canada, China, Denmark, Faroe Island, Japan, and the United States and 
with over 100 participants from all over the world. This paper was written by the presenters of the sessions based on their presentations at the Conference. Dr. Kathryn R. Mahaffey was one of the organizers of the session and cowrote the first draft. Dr. Mahaffey passed away suddenly in June 2, 2009, after decades of significant contributions in the advancement of environmental health particularly in applying the lessons from academic research to protect the public health. All the speakers of the session would like to dedicate this review paper to her memory. We also thank the anonymous reviewers for their constructive comments and suggestions.

\section{REFERENCES}

1. World Health Organization. Diet, nutrition and the prevention of chronic diseases: Report of a joint WHO/FAO expert consultation, 28 January-1 February 2002. World Heath Organization/Food and Agricultural Organization; Geneva: 2003.

2. World Health Organization. Methylmercury. Environmental Health Criteria 101. World Health Organization; Geneva, Switzerland: 1990.

3. Mahaffey KR, Clickner RP, Bodurow CC. Blood organic mercury and dietary mercury intake: National Health and Nutrition Examination Survey, 1999 and 2000. Environ Health Perspect. 2004; 112:562-570. [PubMed: 15064162]

4. Mahaffey K, Clickner R, Jeffries R. Adult women's blood mercury concentrations vary regionally in USA: association with patterns of fish consumption (NHANES 1999-2004). Environ Health Perspect. 2009; 117:47-53. [PubMed: 19165386]

5. Levenson CW, Axelrad DM. Too much of a good thing? Update on fish consumption and mercury exposure. Nutr Rev. 2006; 64:139-145. [PubMed: 16572601]

6. Oken E, Wright RO, Kleinman KP, et al. Maternal fish consumption, hair mercury, and infant cognition in a US cohort. Environ Health Perspect. 2005; 113:1376-1380. [PubMed: 16203250]

7. World Health Organization. Guidance for Identifying Populations at Risk from Mercury Exposure. World Health Organization; Geneva, Switzerland: 2008.

8. Chan HM, Egeland GM. Fish consumption, mercury exposure, and heart diseases. Nutr Rev. 2004; 62:68-72. [PubMed: 15080369]

9. Choi AL, Cordier S, Weihe P, Grandjean P. Negative confounding in the evaluation of toxicity: the case of methyl-mercury in fish and seafood. Crit Rev Toxicol. 2008; 38:877-893. Erratum in 2009;39:95. [PubMed: 19012089]

10. Roman HA, Walsh TL, Coull BA, et al. Evaluation of the cardiovascular effects of methylmercury exposures: current evidence supports development of a dose-response function for regulatory benefits analysis. Environ Health Perspect. 2011; 119:607-614. [PubMed: 21220222]

11. Virtanen JK, Voutilainen S, Rissanen TH, et al. Mercury, fish oils, and risk of acute coronary events and cardiovascular disease, coronary heart disease, and all-cause mortality in men in eastern Finland. Arterioscler Thromb Vasc Biol. 2005; 25:228-233. [PubMed: 15539625]

12. Tan SW, Meiller JC, Mahaffey KR. The endocrine effects of mercury in humans and wildlife. Crit Rev Toxicol. 2009; 39:228-269. [PubMed: 19280433]

13. Valera B, Dewailly E, Poirier P. Environmental mercury exposure and blood pressure among Nunavik Inuit adults. Hyper-tension. 2009; 54:981-986.

14. Kainz M, Telmer K, Mazumder A. Bioaccumulation patterns of methyl mercury and essential fatty acids in lacustrine planktonic food webs and fish. Sci Total Environ. 2006; 368:271-282. [PubMed: 16226794]

15. NAS/NRC. Dietary Reference Intakes for Energy, Carbohydrate, Fiber, Fat, Fatty Acids, Cholesterol, Protein, and Amino Acids (Macronutrients). National Academy of Sciences/National Research Council; Washington, DC: 2005.

16. Yashodhara BM, Umakanth S, Pappachan JM, Bhat SK, Kamath R, Choo BH. Omega-3 fatty acids: a comprehensive review of their role in health and disease. Postgrad Med J. 2009; 85:84-90. [PubMed: 19329703]

17. Burdge GC, Calder PC. Conversion of alpha-linolenic acid to longer-chain polyunsaturated fatty acids in human adults. Reprod Nutr Dev. 2005; 45:581-597. [PubMed: 16188209]

18. Brenna JT. Efficiency of conversion of alpha-linolenic acid to long chain n-3 fatty acids in man. Curr Opin Clin Nutr Metab Care. 2002; 5:127-132. [PubMed: 11844977] 
19. Brenna JT, Salem N, Sinclair AJ, Cunnane SC. Alpha-linolenic acid supplementation and conversion to n-3 long-chain polyunsaturated fatty acids in humans. Prostaglandins Leukot Essent Fatty Acids. 2009; 80:85-91. [PubMed: 19269799]

20. Igarashi M, DeMar JC, Ma KZ, Chang L, Bell JM. Rapoport SI. Docosahexaenoic acid synthesis from alpha-linolenic acid by rat brain is unaffected by dietary n-3 PUFA deprivation. J Lipid Res. 2007; 48:1150-1158. [PubMed: 17277380]

21. German JB, Roberts MA, Watkins SM. Genomics and metabolomics as markers for the interaction of diet and health: lessons from lipids. J Nutr. 2003; 133(Suppl):S2078-S2083.

22. Bourre JM. Dietary omega-3 fatty acids for women. Biomed Pharmacother. 2007; 61:105-112. [PubMed: 17254747]

23. Williams CM, Burdge G. Long-chain n-3 PUFA: plant v. marine sources. Proc Nutr Soc. 2006; 65:42-50. [PubMed: 16441943]

24. Rapoport SI. Brain arachidonic and docosahexaenoic acid cascades are selectively altered by drugs, diet and disease. Prostaglandins Leukot Essent Fatty Acids. 2008; 79:153-156. [PubMed: 18973997]

25. Rapoport SI, Rao JS, Igarashi M. Brain metabolism of nutritionally essential polyunsaturated fatty acids depends on both the diet and the liver. Prostaglandins Leukot Essent Fatty Acids. 2007; 77:251-261. [PubMed: 18060754]

26. DeMar JC, Ma KZ, Bell JM, Rapoport SI. Half-lives of docosahexaenoic acid in rat brain phospholipids are prolonged by 15 weeks of nutritional deprivation of $n-3$ polyunsaturated fatty acids. J Neurochem. 2004; 91:1125-1137. [PubMed: 15569256]

27. Spector AA. Plasma free fatty acid and lipoproteins as sources of polyunsaturated fatty acid for the brain. J Mol Neurosci. 2001; 16:159-165. [PubMed: 11478370]

28. Haggerty P. Effect of placental function on fatty acid requirements during pregnancy. Eur J Clin Nutr. 2004; 58:1559-1570. [PubMed: 15266306]

29. Hanebutt FL, Demmelmair H, Schiessl B, Larque E, Koletzko B. Long-chain polyunsaturated fatty acid (LC-PUFA) transfer across the placenta. Clin Nutr. 2008; 27:685-693. [PubMed: 18639956]

30. Haggerty P. Placental regulation of fatty acid delivery and its effect on fetal growth - a review. Placenta. 2002; 23(Suppl A):528-538.

31. Stewart F, Rodie VA, Ramsay JE, Greer IA, Freeman DJ, Meyer BJ. Longitudinal assessment of erythrocyte fatty acid composition throughout pregnancy and post partum. Lipids. 2007; 42:335344. [PubMed: 17406928]

32. Mahaffey KR. Fish and shellfish as dietary sources of methylmercury and the omega-3 fatty acids, eicosahexaenoic acid and docosahexaenoic acid: risks and benefits. Environ Res. 2004; 95:414428. [PubMed: 15220075]

33. National Academy of Sciences/National Research Council. Seafood Choices: Balancing Benefits and Risks. National Academy Press; Washington, DC: 2006.

34. Weaver KL, Ivester P, Chilton JA, Wilson MD, Pandey P, Chilton FH. The content of favorable and unfavorable polyunsaturated fatty acids found in commonly eaten fish. J Am Diet Assoc. 2008; 108:1178-1185. [PubMed: 18589026]

35. Chung HJ, Nettleton JA, Lemaitre RN, et al. Frequency and type of seafood consumed influence plasma (n-3) fatty acid concentrations. J Nutr. 2008; 138:2422-2427. [PubMed: 19022967]

36. Ozogul Y, Ozogul F, Cicek E, Polat A, Kuley E. Fat content and fatty acid compositions of 34 marine water fish species from the Mediterranean Sea. Int J Food Sci Nutr. 2009; 60:464-475.

37. Osman F, Jaswir I, Khaza'ai H, Hashim R. Fatty acid profiles of fin fish in Lankgkawi Island, Malaysia. J Oleo Sci. 2007; 56:107-113. [PubMed: 17898471]

38. Sidhu KS. Health benefits and potential risks related to consumption of fish or fish oil. Regul Toxicol Pharmacol. 2003; 38:336-344. [PubMed: 14623484]

39. Domingo JL. Omega-3 fatty acids and the benefits of fish consumption: is all that glitters gold? Environ Int. 2007; 33:993-998. [PubMed: 17540446]

40. Sugano M, Hirahara F. Polyunsaturated fatty acids in the food chain in Japan. Am J Clin Nutr. 2000; 71(Suppl):S189-S196. 
41. Rice DC. Overview of modifiers of methylmercury neurotoxicity: chemicals, nutrients, and the social environment. Neurotoxicology. 2008; 29:761-766. [PubMed: 18722469]

42. Brenna JT, Varamini B, Jensen RG, Diersen-Schade DA, Boettcher JA, Arterburn LM. Docosahexaenoic and arachidonic acid concentrations in human breast milk worldwide. Am J Clin Nutr. 2007; 85:1457-1464. [PubMed: 17556680]

43. Innis SM, Friesen RW. Essential n-3 fatty acids in pregnant women and early visual acuity maturation in term infants. Am J Clin Nutr. 2008; 87:548-557. [PubMed: 18326591]

44. Innis, SM. Polyunsaturated fatty acids in human milk - an essential role in infant development. In: Pickering, LK.; Morrow, AL.; RuizPalacios, GM.; Schanler, RJ., editors. Protecting Infants through Human Milk - Advancing the Scientific Evidence. Vol. Vol 554. Kluwer Academic/ Plenum Publ; New York, NY: 2004. p. 27-43.

45. Lewin, G.; Schachter, HM.; Yuen, D., et al. Effects of Omega-3 Fatty Acids on Child and Maternal Health. AHRQ Publication No. 05-E025-2. Agency for Healthcare Research and Quality; Rockville, MD: 2005.

46. McCann JC, Ames BN. Is docosahexaenoic acid, an n-3 long-chain polyunsaturated fatty acid, required for development of normal brain function? An overview of evidence from cognitive and behavioral tests in humans and animals. Am J Clin Nutr. 2005; 82:281-295. [PubMed: 16087970]

47. Helland IB, Smith L, Saarem K, Saugstad OD, Drevon CA. Maternal supplementation with verylong-chain n-3 fatty acids during pregnancy and lactation augments children's IQ at 4 years of age. Pediatrics. 2003; 111:39-44.

48. Dunstan JA, Simmer K, Dixon G. Cognitive assessment of children at age $2 \frac{1}{2} 2$ years after maternal fish oil supplementation in pregnancy: a randomised controlled trial. Arch Dis Child Fetal Neonatal Ed. 2008; 93:F45-F50. [PubMed: 17185423]

49. Grandjean P. Contaminants in fish oil. Am J Clin Nutr. 2005; 82:1354. [PubMed: 16332671]

50. Oken E, Radesky JS, Wright RO, et al. Maternal fish intake during pregnancy, blood mercury levels, and child cognition at age 3 years in a US cohort. Am J Epidemiol. 2008; 167:1171-1181. [PubMed: 18353804]

51. Oken E, Osterdal ML, Gillman MW, et al. Associations of maternal fish intake during pregnancy and breastfeeding duration with attainment of developmental milestones in early childhood: a study from the Danish National Birth Cohort. Am J Clin Nutr. 2008; 88:789-796. [PubMed: 18779297]

52. Hibbeln JR, Davis JM, Steer C, et al. Maternal seafood consumption in pregnancy and neurodevelopmental outcomes in childhood (ALSPAC study): an observational cohort study. Lancet. 2007; 369:578-585. [PubMed: 17307104]

53. Gale CR, Robinson SM, Godfrey KM, Law CM, Schlotz W, O'Callaghan FJ. Oily fish intake during pregnancy - association with lower hyperactivity but not with higher full-scale IQ in offspring. J Child Psychol Psychiatry. 2008; 49:1061-1068. [PubMed: 18422546]

54. Lederman SA, Jones RL, Caldwell KL, et al. Relation between cord blood mercury levels and early child development in a World Trade Center cohort. Environ Health Perspect. 2008; 116:1085-1091. [PubMed: 18709170]

55. American Academy of Pediatrics Committee on Nutrition. New infant formula additives approved by FDA: AAP News. 2002; 20:209-210.

56. Anderson JW, Johnstone BM, Remley DT. Breast-feeding and cognitive development: a metaanalysis. Am J Clin Nutr. 1999; 70:525-535. [PubMed: 10500022]

57. Evenhouse E, Reilly S. Improved estimates of the benefits of breastfeeding using sibling comparisons to reduce selection bias. Health Serv Res. 2005; 40:1781-1802. [PubMed: 16336548]

58. Simmer K, Patole SK, Rao SC. Longchain polyunsaturated fatty acid supplementation in infants born at term. Cochrane Database Syst Rev. 2008; (1):50.

59. Simmer K, Schulzke SM, Patole S. Longchain polyunsatu-rated fatty acid supplementation in preterm infants. Cochrane Database Syst Rev. 2008; (1):48.

60. Smithers LG, Collins CT, Simmonds LA, Gibson RA, McPhee A, Makrides M. Feeding preterm infants milk with a higher dose of docosahexaenoic acid than that used in current practice does not influence language or behavior in early childhood: a follow-up study of a randomized control trial. Am J Clin Nutr. 2010; 91:628-634. [PubMed: 20053878] 
61. Tsubaki, T.; Inkyama, K., editors. Minamata Disease. Elsevier Press; Amsterdam, The Netherlands: 1977.

62. Grandjean P, Weihe P, White RF, et al. Cognitive deficit in 7-year-old children with prenatal exposure to methylmercury. Neurotoxicol Teratol. 1997; 19:417-428. [PubMed: 9392777]

63. Bakir F, Damluji SF, Aminzaki L, et al. Methylmercury poisoning in Iraq - interuniversity report. Science. 1973; 181:230-241. [PubMed: 4719063]

64. Crump KS, Kjellstrom T, Shipp AM, Silvers A, Stewart A. Influence of prenatal mercury exposure upon scholastic and psychological test performance: benchmark analysis of a New Zealand cohort. Risk Anal. 1998; 18:701-713. [PubMed: 9972579]

65. Mergler D, Anderson H, Chan L, et al. Methylmercury exposure and health effects in humans: a worldwide concern. Ambio. 2007; 36:3-11. [PubMed: 17408186]

66. Grandjean, P.; Cordier, S.; Kjellstrom, T.; Weihe, P.; Budtz-Jorgensen, E. Health effects and risk assessments. In: Pirrone, N.; Mahaffey, KR., editors. Dynamics of Mercury Pollution on Regional and Global Scales: Atmospheric Processes and Human Exposure around the World. Springer; Norwell, MA: 2005. p. 499-523.

67. United States Environmental Protection Agency. Regulatory Impact Analysis of the the Clean Air Mercury Rule, Final Report. Office of Air Quality Planning and Standards, U.S. Environmental Protection Agency; Research Triangle Park, NC: 2005.

68. Axelrad DA, Bellinger DC, Ryan LM, Woodruff TJ. Dose-response relationship of prenatal mercury exposure and IQ: an integrative analysis of epidemiologic data. Environ Health Perspect. 2007; 115:609-615. [PubMed: 17450232]

69. Wiener, J.; Krabbenhoft, DP.; Heinz, G.; Sheuhammer, A. Ecotoxicology of mercury. In: Hoffman, D.; Rattner, B.; Burton, BJ.; Cairns, JJ., editors. Handbook of Ecotoxicology. 2nd ed.. CRC Press; Boca Raton, FL: 2003. p. 407-461.

70. Benoit JM, Gilmour CC, Heyes A, Mason RP, Miller C. Geochemical and biological controls over methylmercury production and degradation in aquatic systems. ACS Symp Ser. 2003; 835:262297.

71. Louchouarn P, Lucotte M, Mucci A, Pichet P. Geochemistry of mercury in two hydroelectric reservoirs in Quebec, Canada. Can J Fish Aquat Sci. 1993; 50:269-281.

72. Sunderland EM, Gobas FAPC, Heyes A, et al. Speciation and bioavailability of mercury in wellmixed estuarine sediments. Mar Chem. 2004; 90:91-105.

73. Sunderland EM, Krabbenhoft DP, Moreau JW, Strode SA, Landing WM. Mercury sources, distribution, and bioavailability in the North Pacific Ocean: insights from data and models. Global Biogeochem Cycles. 2009; 23:GB2010. doi:10.1029/2008GB003425.

74. Chan HM, Scheuhammer AM, Ferran A, Loupelle C, Holloway J, Weech S. Impacts of mercury on freshwater fish-eating wildlife and humans. Hum Ecol Risk Assess. 2003; 9:867-883.

75. Kidd K, Hesslein R, Fudge R, Hallard K. The influence of trophic level as measured by delta-N-15 on mercury concentrations in fresh-water organisms. Water Air Soil Pollut. 1995; 80:1011-1015.

76. Bank MS, Chesney E, Shine JP, Maage A, Senn DB. Mercury bioaccumulation and trophic transfer in sympatric snapper species from the Gulf of Mexico. Ecol Appl. 2007; 17:2100-2110. [PubMed: 17974344]

77. Doyon J-F, Schetagne R, Verdon R. Different mercury bioaccumulation rates between sympatric populations of dwarf and normal lake whitefish (Coregonus clupeaformis) in the La Grande complex watershed, James Bay, Quebec. Biogeochemistry. 1998; 40:203-216.

78. Knightes C, Sunderland E, Barber M, Johnston J, Ambrose RJ. Application of ecosystem scale fate and bioaccumulation models to predict fish mercury response times to changes in atmospheric deposition. Environ Toxicol Chem. 2009; 28:881-893. [PubMed: 19391686]

79. Mason RP, Laporte J-M, Andres S. Factors controlling the bioaccumulation of mercury, methylmercury, arsenic, selenium, and cadmium by freshwater invertebrates and fish. Arch Environ Contam Toxicol. 2000; 38:283-297. [PubMed: 10667925]

80. Sunderland EM. Mercury exposure from domestic and imported estuarine and marine fish in the U.S. seafood market. Environ Health Perspect. 2007; 115:235-242. [PubMed: 17384771] 
81. Groth E. Ranking the contributions of commercial fish and shellfish varieties to mercury exposure in the United States: implications for risk communication. Environ Res. 2010; 110:226-236. [PubMed: 20116785]

82. Axtell CD, Cox C, Myers GJ, et al. Association between methylmercury exposure from fish consumption and child development at five and a half years of age in the Seychelles Child Development Study: an evaluation of nonlinear relationships. Environ Res. 2000; 84:71-80. [PubMed: 11068920]

83. Davidson PW, Meyers GJ, Cox C, et al. Longitudinal neurodevelopmental study of Seychellois children following in utero exposure to methylmercury from maternal fish injestion: outcomes at 19 and 29 months. Neurotoxicology. 1995; 16:677-688. [PubMed: 8714872]

84. Davidson PW, Myers GJ, Weiss B, Shamlaye CF, Cox C. Prenatal methyl mercury exposure from fish consumption and child development: a review of evidence and perspectives from the Seychelles Child Development Study. Neurotoxicology. 2006; 27:1106-1109. [PubMed: 16687174]

85. Grandjean P, Jorgensen PJ, Weihe P. Human-milk as a source of methylmercury exposure in infants. Environ Health Perspect. 1994; 102:74-77. [PubMed: 9719671]

86. Grandjean P, Weihe P, Jorgensen PJ, Clarkson T, Cernichiari E, Videro T. Impact of maternal seafood diet on fetal exposure to mercury, selenium, and lead. Arch Environ Health. 1992; 47:185-195. [PubMed: 1596101]

87. Grandjean P, Weihe P, White RF, Debes F. Cognitive performance of children prenatally exposed to "safe" levels of methylmercury. Environ Res. 1998; 77:165-172. [PubMed: 9600810]

88. Kjellstrom, TP.; Kennedy, P.; Wallis, S., et al. Physical and mental development of children with prenatal exposure to mercury from fish: Stage II: Interviews and psychological tests at age 6. Solna; Sweden: 1989. National Swedish Environmental Protection Board Report 3642

89. Marsh DO, Clarkson TW, Cox C, Myers GJ, Aminzaki L, Altikriti S. Fetal methylmercury poisoning - relationship between concentration in single strands of maternal hair and child effects. Arch Neurol. 1987; 44:1017-1022. [PubMed: 2443112]

90. Murata K, Weihe P, Araki S, Budtz-Jorgensen E, Grandjean P. Evoked potentials in Faroese children prenatally exposed to methylmercury. Neurotoxicol Teratol. 1999; 21:471-472. [PubMed: 10440491]

91. Myers GJ, Marsh DO, Cox C, et al. A pilot neurodevelopmental study of Seychellois children following in utero exposure to methylmercury from a maternal fish diet. Neurotoxicology. 1995; 16:629-638. [PubMed: 8714868]

92. van Wijngaarden E, Beck C, Shamlaye CF, et al. Benchmark concentrations for methyl mercury obtained from the 9-year follow-up of the Seychelles child development study. Neurotoxicology. 2006; 27:702-709. [PubMed: 16806480]

93. Murata K, Weihe P, Budtz-Jorgensen E, Grandjean P. Delayed brainstem auditory evoked potential latencies in 14-year old children exposed to methylmercury. J Pediatr. 2004; 144:177-183. [PubMed: 14760257]

94. Debes F, Budtz-Jorgensen E, Weihe P, White RF, Grandjean P. Impact of prenatal methylmercury exposure on neurobehavioral function at age 14 years. Neurotoxicol Teratol. 2006; 28:536-547. [PubMed: 17067778]

95. Budtz-Jorgensen E, Grandjean P, Weihe P. Separation of risks and benefits of seafood intake. Environ Health Perspect. 2007; 115:323-327. [PubMed: 17431478]

96. Myers GJ, Davidson PW, Cox C, et al. Prenatal methyl-mercury exposure from ocean fish consumption in the Seychelles child development study. Lancet. 2003; 361:1686-1692. [PubMed: 12767734]

97. Davidson PW, Strain JJ, Myers GJ, et al. Neurodevelopmental effects of maternal nutritional status and exposure to methylmercury from eating fish during pregnancy. Neurotoxicology. 2008; 29:767-775. [PubMed: 18590763]

98. National Research Council. Toxicological Effects of Methylmercury. National Academy Press; Washington, DC: 2000. 
99. United States Environmental Protection Agency. [Accessed 2 August 2011] Integrated Risk Information System (IRIS): Methylmercury. 2002. Available at: http://www.epa.gov/iris/subst/0073.htm.

100. United States Environmental Protection Agency. Water Quality Criterion for the Protection of Human Health: Methylmercury. Office of Science and Technology, Office of Water; Washington, DC: 2001. EPA-823-R-01-001Available at: http://water.epa.gov/scitech/swguidance/waterquality/standards/criteria/aqlife/pollutants/ methylmercury/document.cfm.

101. Rice DC, Schoeny R, Mahaffey K. Methods and rationale for derivation of a reference dose for methylmercury by the US EPA. Risk Anal. 2003; 23:107-115. [PubMed: 12635727]

102. Health Canada. [Accessed 2 August 2011] Mercury: Your Health and the Environment. 2004. Available at: http://www.hc-sc.gc.ca/ewh-semt/pubs/contaminants/mercur/index-eng.php.

103. World Health Organization. [Accessed February 2010] Joint FAO/WHO Expert Committee on Food Additives. 2003. Available at: http://www.who.int/ipcs/food/jecfa/summaries/en/summary_61.pdf.

104. Food Standards Australia New Zealand (FSANZ). [Accessed Februrary 2010] Mercury in Fish. 2004. Available at:

http://www.foodstandards.gov.au/educationalmaterial/factsheets/factsheets2004/ mercuryinfishfurther2394.cfm.

105. Agency for Toxic Substance and Disease Registry. Toxicologial Profile for Mercury. Agency for Toxic Substance and Disease Registry; 1999. Available at: http://www.atsdr.cdc.gov/toxprofiles/tp46.pdf

106. Grandjean P, Budtz-Jorgensen E. An ignored risk factor in toxicology: the total imprecision of exposure assessment. Pure Appl Chem. 2010; 82:383-391. [PubMed: 20419070]

107. McKelvey W, Gwynn RC, Jeffery N, et al. A biomonitoring study of lead, cadmium, and mercury in the blood of New York city adults. Environ Health Perspect. 2007; 115:1435-1441. [PubMed: 17938732]

108. Tsuchiya A, Hardy J, Burbacher TM, Faustman EM, Fish MK. Fish intake guidelines: incorporating n-3 fatty acid intake and contaminant exposure in the Korean and Japanese communities (vol 87, pg 1867, 2008). Am J Clin Nutr. 2008; 87:1867-1875. [PubMed: 18541579]

109. Tsuchiya A, Hinners TA, Burbacher TM, Faustman EM, Marien K. Mercury exposure from fish consumption within the Japanese and Korean communities. J Toxicol Environ Health Part A. 2008; 71:1019-1031. [PubMed: 18569611]

110. Tsuchiya A, Hinners TA, Krogstad F, et al. Longitudinal mercury monitoring within the Japanese and Korean communities (United States): implications for exposure determination and public health protection. Environ Health Perspect. 2009; 117:1760-1766. [PubMed: 20049129]

111. Kim SA, Jeon CK, Paek DM. Hair mercury concentrations of children and mothers in Korea: implication for exposure and evaluation. Sci Total Environ. 2008; 402:36-42. [PubMed: 18502474]

112. Son JY, Lee J, Paek D, Lee JT. Blood levels of lead, cadmium, and mercury in the Korean population: results from the second Korean national human exposure and bio-monitoring examination. Environ Res. 2009; 109:738-744. [PubMed: 19555934]

113. Feng XB, Qiu GL. Mercury pollution in Guizhou, southwestern China - an overview. Sci Total Environ. 2008; 400:227-237. [PubMed: 18617222]

114. Qiu GL, Feng XB, Li P, et al. Methylmercury accumulation in rice (Oryza sativa L.) grown at abandoned mercury mines in Guizhou, China. J Agric Food Chem. 2008; 56:2465-2468. [PubMed: 18318492]

115. Zhang H, Feng XB, Larssen T, Qiu GL, Vogt RD. In inland China, rice, rather than fish, is the major pathway for methylmercury exposure. Environ Health Perspect. 2010; 118:1183-1188. [PubMed: 20378486]

116. Appleton JD, Weeks JM, Calvez JPS, Beinhoff C. Impacts of mercury contaminated mining waste on soil quality, crops, bivalves, and fish in the Naboc River area, Mindanao, Philippines. Sci Total Environ. 2006; 354:198-211. [PubMed: 16398996] 
117. Larque E, Demmelmair H, Berger B, Hasbargen U, Koletzko B. In vivo investigation of the placental transfer of C-13-labeled fatty acids in humans. J Lipid Res. 2003; 44:49-55. [PubMed: 12518022]

118. Sakamoto M, Kubota M, Liu XH, Murata K, Nakai K, Satoh H. Maternal and fetal mercury and $\mathrm{n}-3$ polyunsaturated fatty acids as a risk and benefit of fish consumption to fetus. Environ Sci Technol. 2004; 38:3860-3863. [PubMed: 15298193]

119. Koletzko B, Larque E, Demmelmair H. Placental transfer of long-chain polyunsaturated fatty acids (LC-PUFA). J Perinat Med. 2007; 35(Suppl):S5-S11. [PubMed: 17302540]

120. Kajiwara Y, Yasutake A, Adachi T, Hirayama K. Methylmercury transport across the placenta via neutral amino acid carrier. Arch Toxicol. 1996; 70:310-314. [PubMed: 8852703]

121. Aschner M, Clarkson TW. Distribution of mercury 203 in pregnant rats and their fetuses following systemic infusions with thiol-containing amino-acids and glutathione during late gestation. Teratology. 1988; 38:145-155. [PubMed: 3175948]

122. Stern AH, Smith AE. An assessment of the cord blood : maternal blood methylmercury ratio: implications for risk assessment. Environ Health Perspect. 2003; 111:1465-1470. [PubMed: 12948885]

123. Morrissette J, Takser L, St-Amour G, Smargiassi A, Lafond J, Mergler D. Temporal variation of blood and hair mercury levels in pregnancy in relation to fish consumption history in a population living along the St. Lawrence River. Environ Res. 2004; 95:363-374. [PubMed: 15220070]

124. Philibert A, Vanier C, Abdelouahab N, Chan HM, Mergler D. Fish intake and serum fatty acid profiles from freshwater fish. Am J Clin Nutr. 2006; 84:1299-1307. [PubMed: 17158409]

125. Burger J. Fishing, fish consumption, and awareness about warnings in a university community in central New Jersey in 2007, and comparisons with 2004. Environ Res. 2008; 108:107-116. [PubMed: 18632098]

126. Burger J, Gochfeld M. Perceptions of the risks and benefits of fish consumption: individual choices to reduce risk and increase health benefits. Environ Res. 2009; 109:343-349. [PubMed: 19193369]

127. Mahaffey KR, Clickner RP, Jeffries RA. Methylmercury and omega-3 fatty acids: co-occurrence of dietary sources with emphasis on fish and shellfish. Environ Res. 2008; 107:20-29. [PubMed: 17996230]

128. Daniels JL, Longnecker MP, Rowland AS, Golding J. Fish intake during pregnancy and early cognitive development of offspring. Epidemiology. 2004; 15:394-402. [PubMed: 15232398]

129. Yavin E, Glozman S, Green P. Docosahexaenoic acid sources for the developing brain during intrauterine life. Nutr Health (Bicester). 2001; 15:219-224.

130. Bezard J, Blond JP, Bernard A, Clouet P. The metabolism and availability of essential fatty-acids in animal and human tissues. Reprod Nutr Dev. 1994; 34:539-568. [PubMed: 7840871]

131. Simopoulos AP. Human requirement for n-3 polyunsatu-rated fatty acids. Poult Sci. 2000; 79:961-970. [PubMed: 10901194]

132. Simopoulos AP. Omega-6, omega-3 essential fatty acids: biological effects. World Rev Nutr Diet. 2009; 99:1-16. [PubMed: 19136835]

133. Arterburn LM, Hall EB, Oken H. Distribution, interconversion, and dose-response of n-3 fatty acids in humans. Am J Clin Nutr. 2006; 83(Suppl):S1467-S1476.

134. Gao F, Kiesewetter D, Chang L, Ma KZ, Rapoport SI, Igarashi M. Whole-body synthesis secretion of docosahexaenoic acid from circulating eicosapentaenoic acid in unanesthetized rats. J Lipid Res. 2009; 50:2463-2470. [PubMed: 19571329]

135. Davis BC, Kris-Etherton PM. Achieving optimal essential fatty acid status in vegetarians: current knowledge and practical implications. Am J Clin Nutr. 2003; 78(Suppl):S640-S646.

136. Bhaskar N, Kinami T, Miyashita K, Park SB, Endo Y, Fujimoto K. Occurrence of conjugated polyenoic fatty acids in seaweeds from the Indian Ocean. Z Naturforsch [C]. 2004; 59:310-314.

137. Polat S, Ozogul Y. Biochemical composition of some red and brown macro algae from the northeastern Mediterranean Sea. Int J Food Sci Nutr. 2008; 59:566-572. [PubMed: 19382347]

138. Harwood JL, Guschina IA. The versatility of algae and their lipid metabolism. Biochimie. 2009; 91:679-684. [PubMed: 19063932] 
139. Barcelo-Coblijn G, Murphy EJ, Othman R, Moghadasian MH, Kashour T, Friel JK. Flaxseed oil and fish-oil capsule consumption alters human red blood cell n-3 fatty acid composition: a multiple-dosing trial comparing 2 sources of n-3 fatty acid. Am J Clin Nutr. 2008; 88:801-809. [PubMed: 18779299]

140. Strijbosch RAM, Lee S, Arsenault DA, et al. Fish oil prevents essential fatty acid deficiency and enhances growth: clinical and biochemical implications. Metab Clin Exp. 2008; 57:698-707. [PubMed: 18442636]

141. Or-Rashid MM, Odongo NE, Wright TC, McBride BW. Fatty acid profile of bovine milk naturally enhanced with docahexaenoic acid. J Agric Food Chem. 2009; 57:1366-1377. [PubMed: 19191559]

142. Doughman SD, Krupanidhi S, Sanjeevi CB. Omega-3 fatty acids for nutrition and medicine: considering microalgae oil as a vegetarian source of EPA and DHA. Curr Diabetes Rev. 2007; 3:198-203. [PubMed: 18220672]

143. Arterburn LM, Oken HA, Hall EB, Hamersley J, Kuratko CN, Hoffman JP. Algal-oil capsules and cooked salmon: nutritionally equivalent sources of docosahexaenoic acid. J Am Diet Assoc. 2008; 108:1204-1209. [PubMed: 18589030]

144. Herber SM, VanElswyk ME. Dietary marine algae promotes efficient deposition of n-3 fatty acids for the production of enriched shell eggs. Poult Sci. 1996; 75:1501-1507. [PubMed: 9000275]

145. Meyer BJ, Mann NJ, Lewis JL, Milligan GC, Sinclair AJ, Howe PRC. Dietary intakes and food sources of omega-6 and omega-3 polyunsaturated fatty acids. Lipids. 2003; 38:391-398. [PubMed: 12848284]

146. Caston L, Leeson S. Research note - dietary flax and egg consumption. Poult Sci. 1990; 69:16171620.

147. Cherian G, Sim J. Effect of feeding full-fat flax and canola seeds to laying hens on the fatty acid composition of eggs, embryos, and post-hatch chicks. Poult Sci. 1991; 70:917-922.

148. Butarbutar TB. Fatty acid and cholesterol in eggs: a review. Southeast Asian J Trop Med Public Health. 2004; 35:1036-1038. [PubMed: 15916112]

149. Dewailly E, Rouja P, Dallaire R, et al. Balancing the risks and the benefits of local fish consumption in Bermuda. Food Addit Contam Part A-Chem. 2008; 25:1328-1338.

150. Del Gobbo LC, Archbold JA, Vanderlinden LD, Eckley CS, Diamond ML, Robson M. Risks and benefits of fish consumption for childbearing women. Can J Diet Pract Res. 2010; 71:41-45. [PubMed: 20205977]

151. Verger P, Khalfi N, Roy C, Blanchemanche S, Marette S, Roosen J. Balancing the risk of dioxins and polychlorinated biphenyls (PCBs) and the benefit of long-chain polyunsatu-rated fatty acids of the n-3 variety for French fish consumers in western coastal areas. Food Addit Contam. 2008; 25:765-771.

152. Domingo JL, Bocio A, Falco G, Llobet JM. Benefits and risks of fish consumption Part I. A quantitative analysis of the intake of omega-3 fatty acids and chemical contaminants. Toxicology. 2007; 230:219-226. [PubMed: 17161894]

153. Chien LC, Gao CS, Lin HH. Hair mercury concentration and fish consumption: risk and perceptions of risk among women of childbearing age. Environ Res. 2010; 110:123-129. [PubMed: 19878931]

154. Verger P, Houdart S, Marette S, Roosen J, Blanchemanche S. Impact of a risk-benefit advisory on fish consumption and dietary exposure to methylmercury in France. Regul Toxicol Pharmacol. 2007; 48:259-269. [PubMed: 17566619]

155. Oken E, Kleinman KP, Berland WE, Sitnn SR, Rich-Edwards JW, Gillman MW. Decline in fish consumption among pregnant women after a national mercury advisory. Obstet Gynecol. 2003; 102:346-351. [PubMed: 12907111]

156. Costa LG. Contaminants in fish: risk-benefit considerations. Arh Hig Rada Toksikol. 2007; 58:367-374. [PubMed: 17913692]

157. Chapman L, Chan HM. The influence of nutrition on methyl mercury intoxication. Environ Health Perspect. 2000; 108:29-56. [PubMed: 10698722] 
158. Sioen I, De Henauw S, Van Camp J, Volatier JL, Leblanc JC. Comparison of the nutritionaltoxicological conflict related to seafood consumption in different regions worldwide. Regul Toxicol Pharmacol. 2009; 55:219-228. [PubMed: 19589366]

159. Mozaffarian D. Fish, mercury, selenium and cardiovascular risk: current evidence and unanswered questions. Int J Environ Res Public Health. 2009; 6:1894-1916. [PubMed: 19578467]

160. Mozaffarian D, Rimm EB. Fish intake, contaminants, and human health - evaluating the risks and the benefits. JAMA. 2006; 296:1885-1899. [PubMed: 17047219]

161. Myers GJ, Davidson PW, Strain JJ. Nutrient and methyl mercury exposure from consuming fish. J Nutr. 2007; 137:2805-2808. [PubMed: 18029503]

162. Strain JJ, Davidson PW, Bonham MP, et al. Associations of maternal long-chain polyunsaturated fatty acids, methyl mercury, and infant development in the Seychelles Child Development Nutrition Study. Neurotoxicology. 2008; 29:776-782. [PubMed: 18590765]

163. Ginsberg G, Toal B. Quantitative approach for incorporating methyl mercury risks and omega-3 fatty acid benefits in developing species-specific fish consumption advice. Environ Health Perspect. 2009; 117:267-275. [PubMed: 19270798]

164. Guevel MR, Sirot V, Volatier JL, Leblanc JC. A risk-benefit analysis of French high fish consumption: a QALY approach. Risk Anal. 2008; 28:37-48. [PubMed: 18304105]

165. Saint-Amour D, Roy MS, Bastien C, et al. Alterations of visual evoked potentials in preschool Inuit children exposed to methylmercury and polychlorinated biphenyls from a marine diet. Neurotoxicology. 2006; 27:567-578. [PubMed: 16620993]

166. Sakamoto M, Kubota M, Murata K, Nakai K, Sonoda I, Satoh H. Changes in mercury concentrations of segmental maternal hair during gestation and their correlations with other biomarkers of fetal exposure to methylmercury in the Japanese population. Environ Res. 2008; 106:270-276. [PubMed: 18054904]

167. United States Department of Agriculture. [Accessed February, 2010] Nutrient Data Laboratory. 2010. Available at: http://www.nal.usda.gov/fnic/foodcomp/search/. 


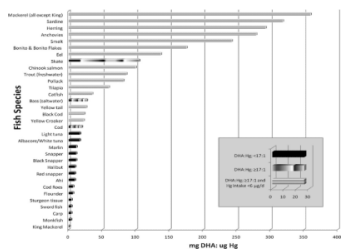

Figure 1. Examples of fish species that, when consumed, allow an individual to meet the daily recommended intake for DHA while not exceeding the US EPA RfD, prepared according to the methodology described by Tsuchiya et al. ${ }^{108}$

Fish species are divided into three categories: species that provide levels below and above a de minimus intake ratio of $17 \mathrm{mg}$ DHA for every $1 \mu \mathrm{g} \mathrm{Hg}$ and species that exceed this ratio while also providing for a $\mathrm{Hg}$ intake of less than $6 \mu \mathrm{g}$ of $\mathrm{Hg}$ exposure per day. Values are based on intakes equivalent to the RfD by an individual weighing $60 \mathrm{~kg}$ and consuming 60 g/day. 
Table 1

NHANES (1999-2002) frequency of consumption rank and corresponding concentrations of the long-chain omega-3 fatty acids (eicosapentaenoic and docosahexaenoic acid) (from Mahaffey ${ }^{32}$ ) and $\mathrm{Hg}$ concentrations (Sunderland ${ }^{80}$ and references therein).

\begin{tabular}{|c|c|c|c|}
\hline Rank & Species & EPA + DHA milligrams $/ 100 \mathrm{~g}$ of fish & Hg milligrams/ $1,000 \mathrm{~g}$ of fish ${ }^{*}$ \\
\hline 1 & Shrimp & 390 & $0.03-0.04$ \\
\hline \multirow[t]{8}{*}{2} & Tuna (all, average) & 630 & $0.24-0.48$ \\
\hline & Canned $^{\frac{1}{t}}:$ & & \\
\hline & Light (skipjack) & $128^{\S}-270^{I I}$ & $0.11-0.12$ \\
\hline & White (albacore) & $862^{\S}$ & $0.35-0.37$ \\
\hline & Fresh: & & \\
\hline & Bluefin (7 kg) & $1,173^{* *}-1,504^{\dagger \dagger}$ & 0.13 \\
\hline & Skipjack (3 kg) & $256^{* *}-328^{\dagger \dagger}$ & 0.17 \\
\hline & Yellowfin $(5-20 \mathrm{~kg})$ & $100^{* *}-120^{\dagger \dagger}$ & $0.06-0.31$ \\
\hline 3 & Breaded fish products & 0.26 & $0.135^{\dagger}$ \\
\hline 4 & Salmon & 1,590 & $0.04-0.13$ \\
\hline 5 & Crabs & 36 & $0.06-0.26$ \\
\hline 6 & Catfish & 280 & $0.16^{\dagger}$ \\
\hline 7 & Other fish & 54 & $0.223^{\dagger}$ \\
\hline 8 & Scallops & 270 & 0.05 \\
\hline 9 & Lobster & 360 & $0.10-0.28$ \\
\hline 10 & Clams & 240 & $0.01-0.06$ \\
\hline 11 & Cod & 240 & $0.06-0.11$ \\
\hline 12 & Oysters & 350 & $0.01-0.07$ \\
\hline 13 & Other shellfish & 310 & $0.061^{\dagger}$ \\
\hline 14 & Flatfish & 15 & $0.092^{\dagger}$ \\
\hline 15 & Unknown fish & 53 & $0.223^{\dagger}$ \\
\hline 16 & Pollock & 260 & $0.02-0.06$ \\
\hline 17 & Mussels & 350 & $0.03-0.08$ \\
\hline 18 & Trout & 580 & $0.14-0.15^{\dagger}$ \\
\hline 19 & Haddock & 180 & $0.03-0.06$ \\
\hline 20 & Crayfish & 380 & 0.03 \\
\hline 21 & Perch & 300 & $0.09-0.11^{\dagger}$ \\
\hline 22 & Sardines & 980 & $0.02-0.03$ \\
\hline 23 & Swordfish & 580 & $0.98-1.03$ \\
\hline 24 & Bass (freshwater) & 640 & $0.38^{\dagger}$ \\
\hline 25 & Sea bass & 490 & $0.14-0.22$ \\
\hline
\end{tabular}




\begin{tabular}{|c|c|c|c|}
\hline Rank & Species & EPA + DHA milligrams $/ 100 \mathrm{~g}$ of fish & Hg milligrams/ 1,000 g of fish ${ }^{*}$ \\
\hline 26 & Pike & 140 & $0.31^{\dagger}$ \\
\hline \multirow[t]{2}{*}{27} & Mackerel (except King) & 1,790 & $0.09-0.220$ \\
\hline & King mackerel & 401 & $0.73-1.06$ \\
\hline 28 & Shark & 220 & $0.75-0.99$ \\
\hline 29 & Walleye & 530 & $0.52^{\dagger}$ \\
\hline 30 & Porgy & 210 & 0.08 \\
\hline \multicolumn{4}{|c|}{ Ranges in $\mathrm{Hg}$ concentrations represent variability in sample means across different harvesting regions. } \\
\hline \multicolumn{4}{|c|}{${ }^{\dagger}$ Data from Mahaffey et al., $2004^{3}$ and references therein. } \\
\hline \multicolumn{4}{|c|}{ Data from USDA. 167} \\
\hline \multicolumn{4}{|c|}{$\S_{\text {Tuna canned in water, drained solids. }}$} \\
\hline \multicolumn{4}{|c|}{ II Tuna canned in oil, drained solids. } \\
\hline \multicolumn{4}{|l|}{ *** Raw. } \\
\hline Cooke & ry heat. & & \\
\hline
\end{tabular}

